\title{
Spectrofluorimetric and Spectrophotometric Stability-Indicating Methods for Determination of Some Oxicams Using 7-Chloro-4-nitrobenz-2-oxa- 1,3-diazole (NBD-Cl)
}

\author{
Elham Anwer TAHA, ${ }^{* a}$ Nahla Nour SAlAma, ${ }^{a}$ and Laila El-Sayed Abdel FATTAH ${ }^{b}$ \\ ${ }^{a}$ National Organization for Drug Control and Research; 6 Abou Hazem Street, Pyramids Ave, P.O. Box 29 Giza, Egypt: \\ and ${ }^{b}$ Department of Analytical Chemistry, Faculty of Pharmacy, Cairo Univerisity; Kasr El-Eini Street, 11562 Cairo, \\ Egypt. Received December 12, 2005; accepted February 8, 2006
}

\begin{abstract}
Two sensitive and selective spectrofluorimetric and spectrophotometric stability-indicating methods have been developed for the determination of some non-steroidal anti-inflammatoy oxicam derivatives namely lornoxicam (Lx), tenoxicam ( $T x)$ and meloxicam $(M x)$ after their complete alkaline hydrolysis. The methods are based on derivatization of alkaline hydrolytic products with 7-chloro-4-nitrobenz-2-oxa-1,3-diazole (NBD-Cl). The products showed an absorption maximum at $460 \mathrm{~nm}$ for the three studied drugs and fluorescence emission peak at $535 \mathrm{~nm}$ in methanol. The color was stable for at least $48 \mathrm{~h}$. The optimum conditions of the reaction were investigated and it was found that the reaction proceeds quantitatively at $\mathrm{pH} 8$, after heating in a boiling water bath for $30 \mathrm{~min}$. The methods were found to be linear in the ranges of $1-10 \mu \mathrm{g} \mathrm{ml}^{-1}$ for $\mathrm{Lx}$ and Tx and $0.5-4.0 \mu \mathrm{g}$ $\mathrm{ml}^{-1}$ for Mx for spectrophotometric method, while $0.05-1.0 \mu \mathrm{g} \mathrm{ml}^{-1}$ for $\mathrm{Lx}$ and $\mathrm{Tx}$ and $0.025-0.4 \mu \mathrm{g} \mathrm{ml}^{-1}$ for Mx for the spectrofluorimetric method. The validity of the methods was assessed according to USP guidelines. Statistical analysis of the results revealed high accuracy and good precision. The suggested procedures could be used for the determination of the above mentioned drugs in pure and dosage forms as well as in the presence of their degradation products.
\end{abstract}

Key words 7-chloro-4-nitrobenz-2-oxa-1,3-diazole; dosage form; oxicam; spectrofluorimetry; spectrophotometry; stability-indicating assay

Lornoxicam (Lx), 6-chloro-4-hydroxy-2-methyl- $N$-2pyridinyl-2H-thieno[2,3-e]-1,2-thiazine-3-carboxamide 1,1 dioxide, ${ }^{1)}$ tenoxicam (Tx), 4-hydroxy-2-methyl- $N$-(pyridine2-yl)-2H-thieno[2,3-e]-1,2-thiazine-3-carboxamide 1,1-diox$\mathrm{ide}^{2)}$ and meloxicam (Mx), 4-hydroxy-2-methyl- $\mathrm{N}$-(5-methyl1,3-thiazol-2-yl)-2H-1,2-benzothiazine-3-carboxamide 1,1dioxide, ${ }^{2)}$ are new non-steroidal anti-inflammatory drugs (NSAIDs) of oxicam class. They are used in the treatment of rheumatoid arthritis, osteoarthritis and related conditions. ${ }^{3)}$ The pharmacological actions of these oxicams are related to inhibition of cyclooxygenase (Cox), a key enzyme of prostaglandine biosynthesis at the site of inflammation. ${ }^{4)} \mathrm{Lx}$ is distinguished from established oxicams by a relatively short elimination half-life, which may be advantageous from a tolerability stand point. ${ }^{5} \mathrm{Mx}$ is suggested to be a selective Cox-2 inhibitor. ${ }^{4)}$ The official methods for the determination of Tx and Mx are non aqueous titration with perchloric acid, determining the end point potentiometrically. ${ }^{2)} \mathrm{Lx}$ is not official in any pharmacopoeia and a literature survey revealed that few attempts have been made as stability indicating methods, spectrophotometric, ${ }^{6}$ electrochemical ${ }^{7}$ and few HPLC $^{8-10)}$ methods were reported for its determination. For Tx, different methods were reported including spectrophotometric, ${ }^{6,11-13)}$ fluorimetric, ${ }^{13-15)}$ infrared, ${ }^{16)}$ electrochemical $^{17-19)}$ and HPLC $^{8,20)}$ methods. For Mx, spectrophotometric, ${ }^{6,13,21-23)}$ fluorimetric, ${ }^{13,24)}$ electrochemical ${ }^{25,26)}$ and HPLC $^{8,23,27,28)}$ methods were reported.

Among the various methods available for the determination of drugs, spectrophotometry and spectrofluorimetry continue to be very popular, because of their simplicity, specificity and low cost. This study presents a new spectrophotometric and spectrofluorimetric methods for the assay of $\mathrm{Lx}$, Tx and Mx. The methods are based on derivatization with 7-chloro-4-nitrobenz-2-oxa-1,3-diazole (NBD-Cl) which is highly sensitive and selective reagent for primary and secondary amines. NBD derivatives are usually determined fluorimetrically, ${ }^{29,30)}$ however, photometric detection has also occasionally been used. ${ }^{31,32)}$

The aim of this study was to optimize the reaction between the alkaline hydrolytic products of the three studied drugs and NBD-Cl.

The applicability of the developed methods was evaluated through the determination of Lx, Tx and Mx in bulk powder, in laboratory prepared mixtures containing different percentages of degradation products as well as in pharmaceutical dosage forms.

\section{Experimental}

Materials Spectrophotometric measurements were carried out using a SHIMADZU UV-1601 with $1 \mathrm{~cm}$ quartz cells. Fluorescence spectra and measurements were taken on a SHIMADZU spectrofluorimeter Model RF1501 equipped with xenon lamp and 1-cm glass cells. Excitation and emission wavelengths were set at 460 and $535 \mathrm{~nm}$ respectively. Digital $\mathrm{pH}$ meter HANNA 8417 was used.

All chemicals used were of analytical grade Methanol (Lab. Scan), Acetone (El-Naser Co. Egypt). Lx, was kindly supplied by October Pharm Co. (Egypt). The purity of the sample was found to be $100.0 \pm 0.7$ according to the reported method (a method supplied by personal communication from the manufacturer Co.). Xefo tablets (October Pharm. Co.) are labeled to contain $8 \mathrm{mg} /$ tablet. Tx, was kindly obtained from Epico Co. (Egypt), its purity was labeled to be $99.7 \pm 0.9$ according to the official method. ${ }^{2)}$ Epicotil tablets and vials (Epico Co. Egypt), are labeled to contain $20 \mathrm{mg} /$ tablet or vial. Mx, was kindly supplied by Adwia Co. (Egypt). The purity of the sample was found to be $99.9 \pm 0.8$ according to the official method. ${ }^{2)}$ AnticoxII tablets, ampoules and capsules (Adwia Co., Egypt) are labeled to contain $15 \mathrm{mg} /$ tablet or ampoule and $7.5 \mathrm{mg} / \mathrm{capsule}$.

NBD-Cl (Sigma): NBD-Cl $0.4 \%$ in acetone was freshly prepared.

Buffer: Borate buffer, $\mathrm{pH} 8$ was prepared by dissolving $0.620 \mathrm{~g}$ boric acid and $0.750 \mathrm{~g}$ potassium chloride in $50 \mathrm{ml}$ of water. The $\mathrm{pH}$ was adjusted with $0.1 \mathrm{~m}$ sodium hydroxide solution and the volume was made up to $200 \mathrm{ml}$ with water.

Sample Preparations Lornoxicam, Tenoxicam and Meloxicam Alka- 
line Degradates Stock Standard Solution (Series A), $\left(100 \mu \mathrm{g} \mathrm{ml}^{-1}\right)$ : About $10 \mathrm{mg}$ of each of Lx, Tx and Mx were accurately weighed and separately transferred into three $100-\mathrm{ml}$ conical flasks. Twenty milliliters of $2 \mathrm{~m}$ sodium hydroxide were added to each flask and heated in a boiling water bath for 15 , 10, $30 \mathrm{~min}$ for Lx, Tx and Mx respectively. After cooling $2 \mathrm{M}$ hydrochloric acid was added for each drug solution till the $\mathrm{pH}$ was adjusted to 9. Each solution was transferred quantitatively to $100-\mathrm{ml}$ volumetric flask. The volume was completed to the mark with distilled water. Standard working solutions $\left(10,20,40,60,80,100 \mu \mathrm{g} \mathrm{ml}^{-1}\right.$ for $\mathrm{Lx}$ and Tx alkaline degradates, while 5 , $10,20,30,40 \mu \mathrm{g} \mathrm{ml}^{-1}$ for Mx alkaline degradate) were prepared by suitable dilution of the obtained stock solutions of standard degradates, these solutions were used for spectrophotometric method. For spectrofluorimetric method, the standard working solutions were further diluted ten times in 10$\mathrm{ml}$ volumetric flasks.

Lornoxicam, Tenoxicam and Meloxicam Standard Stock Solutions (Series B), $\left(100 \mu \mathrm{g} \mathrm{ml}^{-1}\right)$ : They were prepared by accurately weighing $10 \mathrm{mg}$ of each of Lx, Tx and Mx powder and transferred separately into 100-ml volumetric flasks. They were dissolved in $1.0 \mathrm{ml}$ of $0.1 \mathrm{~m}$ sodium hydroxide, $80 \mathrm{ml}$ of distilled water was added for each drug and $\mathrm{pH}$ was adjusted to 9 . Then the volume was completed to the mark with distilled water. Standard working solutions $\left(10,20,40,60,80,100 \mu \mathrm{g} \mathrm{ml}^{-1}\right.$ for Lx and Tx while 5, $10,20,30,40 \mu \mathrm{g} \mathrm{ml}^{-1}$ for $\mathrm{Mx}$ ) were prepared by appropriate dilution with distilled water. These solutions were used for spectrophotometric method. For spectrofluorimetric method, the standard working solutions were further diluted ten times in 10-ml volumetric flasks.

Analytical Procedures Spectrophotometric Method: Aliquots equivalent to $40 \mu \mathrm{g}$ of each of Lx and Mx while $100 \mu \mathrm{g}$ of Tx alkaline degradates were separately transferred from their working standard solutions (series A) into three test tubes. The solutions were mixed each with $1 \mathrm{ml}$ of borate buffer $\mathrm{pH}$ 8. After addition of $0.6 \mathrm{ml}$ of NBD-Cl solution $(0.4 \% \mathrm{w} / \mathrm{v})$, the mixtures were heated for $30 \mathrm{~min}$ in a boiling water bath. Then they were cooled and acidified with $0.1 \mathrm{ml}$ of $0.1 \mathrm{~m}$ hydrochloric acid. The reaction products solutions were transferred quantitatively into three 10 -ml volumetric flasks, the volume was completed to the mark with methanol. The difference in absorption spectra of the obtained solutions and blanks of their corresponding concentration similarly treated but without hydrolysis were recorded in range $350-700 \mathrm{~nm}$.

Spectrofluorimetric Method: One milliliter of each of the obtained solution under "Spectrophotometric Method" were transferred into 10-ml volumetric flask and diluted with methanol. The difference in fluorescence intensity was measured at $\lambda_{\mathrm{em}} 535 \mathrm{~nm}$ using $\lambda_{\mathrm{ex}} 460 \mathrm{~nm}$ for each of the three studied drugs against its corresponding drug concentration without hydrolysis and similarly treated.

Assay of Dosage Forms An accurately weighed amount of ten tablets, capsules, or vials powder, and equivalent milliliters of six ampoules, equivalent to $40 \mathrm{mg}$ of the cited drugs, were transferred into $100-\mathrm{ml}$ volumetric flask, $80-\mathrm{ml}$ of acetone was added and shaken for $30 \mathrm{~min}$. The volume was diluted to the mark with acetone, mixed and filtered. A $25-\mathrm{ml}$ of each of Lx, Tx and Mx were transferred into three 100-ml conical flasks evaporated on a boiling water bath to dryness. One milliliter of $0.1 \mathrm{~m}$ sodium hydroxide and $80 \mathrm{ml}$ water were added for each flask. They were transferred quantitatively into three $100-\mathrm{ml}$ volumetric flasks and proceed as under "Lornoxicam, Tenoxicam and Meloxicam Standard Stock Solutions" (series B). Another $25-\mathrm{ml}$ of each drug was transferred separately into three 100-ml conical flask. Each solution was evaporated to dryness on a boiling water bath, 20 $\mathrm{ml}$ of $2 \mathrm{M}$ sodium hydroxide was added and proceed as under "Lornoxicam, Tenoxicam and Meloxicam Alkaline Degradates Stock Standard Solution" (series A). The procedures were followed as under "Spectrophotometric Method", "Spectrofluorimetric Method" for spectrophotometric and spectrofluorimetric methods respectively.

Method Validation Linearity: Aliquots equivalent to $10-100 \mu \mathrm{g}$ of Lx and $\mathrm{Tx}$ and equivalent to $5-40 \mu \mathrm{g}$ of $\mathrm{Mx}$ were separately transferred from working standard solutions (series A), into a series of test tubes. The procedure under "Spectrophotometric Method" was followed. The difference in absorbance was measured at $460 \mathrm{~nm}$ for the three studied drugs. Each measurement was recorded against its corresponding concentration without hydrolysis and similarly treated. The $\Delta A$ values obtained were plotted against the corresponding concentrations. The regression equations were calculated.

Spectrofluorimetrically, aliquots equivalent to $5-100 \mu \mathrm{g}$ of $\mathrm{Lx}$ and $\mathrm{Tx}$, while $2.5-40 \mu \mathrm{g}$ of $\mathrm{Mx}$ were separately transferred from their working standard solutions (series A). The procedure was proceeded as under "Spectrofluorimetric Method". The fluorescence intensity was measured at $\lambda_{\mathrm{em}}$ $535 \mathrm{~nm}$ using $\lambda_{\text {ex }} 460 \mathrm{~nm}$ for the three cited drugs. The difference in fluores- cence intensity between each concentration and the corresponding concentration without hydrolysis and similarly treated was recorded. The $\Delta F$ (difference in fluorescence intensity) values obtained were plotted against the corresponding concentrations. The regression equations were calculated.

Accuracy: The previously mentioned procedures under study of linearity were repeated four times for determination of five different concentrations of pure samples of Lx, Tx and Mx. The recovery percentages and mean recoveries were calculated from their corresponding regression equations.

Precision: Intraday precision was evaluated for the three studied drugs by assaying freshly prepared solutions in triplicate at concentrations 1,2 and $4 \mu \mathrm{g} \mathrm{ml}^{-1}$ while $0.1,0.2$ and $0.4 \mu \mathrm{g} \mathrm{ml}^{-1}$ for spectrophotometric and spectrofluorimetric methods respectively. The relative standard deviation was calculated. The interday precision of the proposed methods was calculated from assaying freshly prepared solutions in triplicate for $3 \mathrm{~d}$. The relative standard deviation was then calculated.

Specificity: Aliquots equivalent to $(90-10 \mu \mathrm{g})$ of each of $\mathrm{Lx}$ and $\mathrm{Tx}$, while equivalent to $(36.0-4.0 \mu \mathrm{g})$ of $\mathrm{Mx}$ for spectrophotometric and spectrofluorimetric methods, were separately transferred from their working standard solutions (series B) into 10-ml volumetric flasks for spectrophotometric and spectrofluorimetric methods for the three cited drugs. To the previous solutions aliquots equivalent to $(10-90 \mu \mathrm{g})$ of $\mathrm{Lx}$ and $\mathrm{Tx}$ while equivalent to $(4.0-36.0 \mu \mathrm{g})$ for $\mathrm{Mx}$ from their working standard solutions (series A). The obtained solutions contained degradates in the range of 10 $90 \%$. Then the assay was completed as under "Spectrophotometric Method", "Spectrofluorimetric Method". for spectrophotometric and spectrofluorimetric methods respectively.

Standard Addition Technique: The detailed procedures mentioned under linearity were adopted for the determination of the drugs in their dosage forms and the standard addition technique was applied to assess the accuracy of the method according USP2 8 guidelines. The concentrations were calculated from their corresponding regression equations.

\section{Results and Discussion}

NBD-Cl is a reagent known to react with aromatic amines through electrophilic substitution. The studied drugs Lx, Tx and $\mathrm{Mx}$ do not contain primary amino group, while upon hydrolysis with alkali the cleavage of weak amide group occurs with production of primary amine, 2-aminopyridine (2-AP) for Lx and Mx and 2-amino-5-methylthiazole (2-AMT) for $\mathrm{Mx}$. These primary amines react with $\mathrm{NBD}-\mathrm{Cl}$ and the reaction product has fluorescence intensity at $\lambda_{\mathrm{em}} 535 \mathrm{~nm}$ upon excitation with $460 \mathrm{~nm}$ and yellowish brown color with $\lambda_{\max }$ $460 \mathrm{~nm}$. The proposed NBD-Cl method extend to develop a stability indicating assay for the three studied drugs. These drugs are liable to alkaline hydrolysis, the process of hydrolysis was found to be accelarated by elevating the temperature and increasing the basicity of the medium. It was found that $2 \mathrm{~m}$ sodium hydroxide and heating for $15,10,30 \mathrm{~min}$ for $\mathrm{Lx}$, Tx and Mx respectively gave complete hydrolysis. The suggested mechanism of reaction can be interpreted as in Chart 1 .

The present work depends on measuring the difference in absorbance at $\lambda 460 \mathrm{~nm}$ in spectrophotometric method and difference in fluorescence intensities at $\lambda_{\text {em }} 535 \mathrm{~nm}$ upon excitation with $\lambda_{\mathrm{ex}} 460 \mathrm{~nm}$ of two solutions of the same concentration of each of Lx, Tx and Mx before and after complete alkaline hydrolysis. Hence, any degradation products intially present in Lx, Tx or Mx samples will be subtracted from the readings of the experiment at the corresponding wavelength after hydrolysis and the difference in absorbance before and after hydrolysis will be corresponding only to the intact drug.

The fluorescence intensity at $\lambda_{\text {em }} 535 \mathrm{~nm}$ before and after hydrolysis was also applied for the determination of only intact Lx, Tx and Mx samples as any degradation product in Lx, Tx and Mx samples will be canceled.

Spectrophotometric Method The spectra of the alka- 

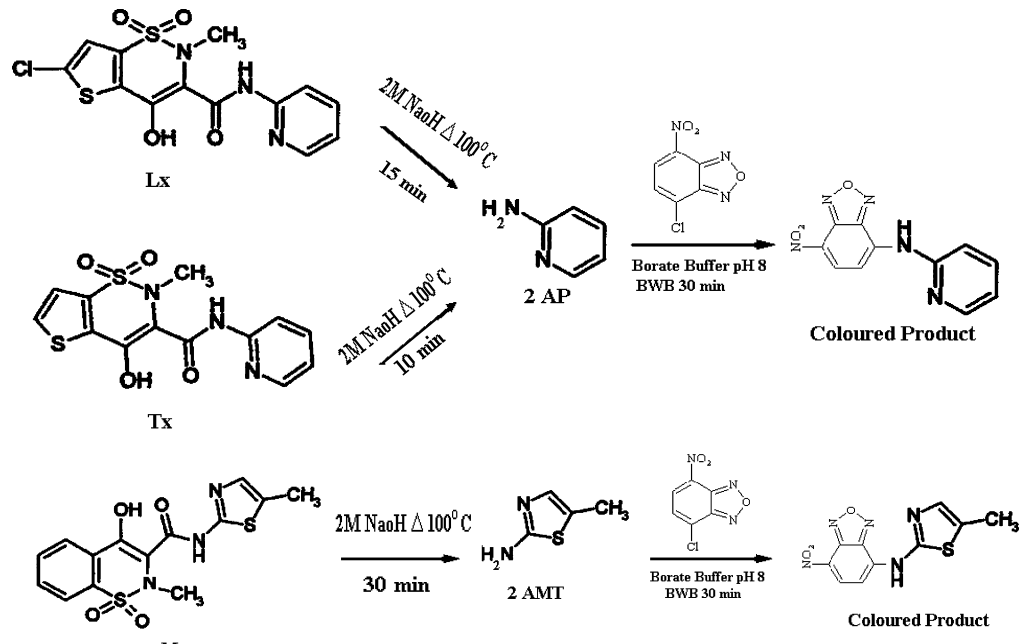

Mx

Chart 1. The Suggested Mechanism of Reaction between the Alkaline Hydrolytic Products of Lx, Tx, Mx and NBD-Cl

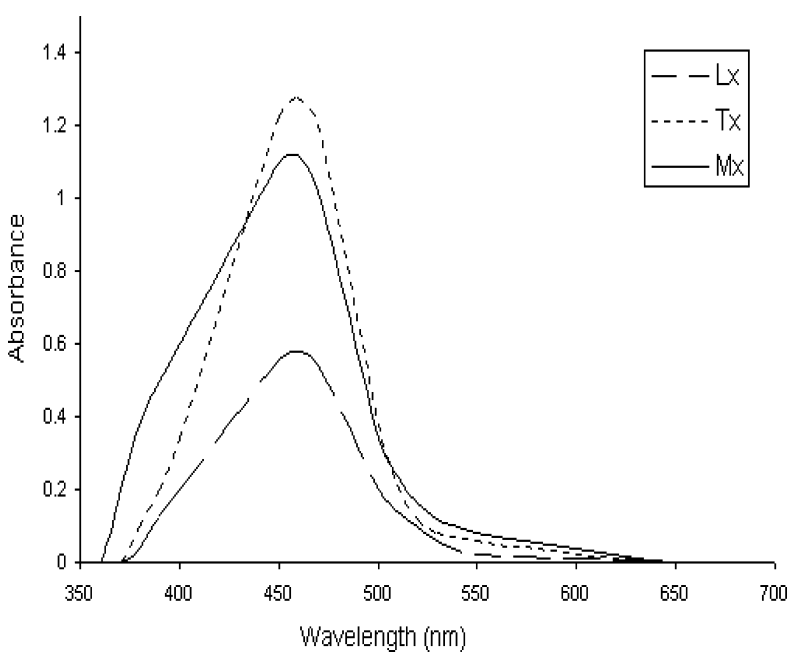

Fig. 1. Zero-Order Absorption Spectra of, $4 \mu \mathrm{g} \mathrm{ml}^{-1}$ of Each of Lornoxicam, Lx and Meloxicam, Mx and $10 \mu \mathrm{g} \mathrm{ml}^{-1}$ of Tenoxicam, Tx-Alkaline Degradate NBD-Cl Reaction Product Each against Its Corresponding Concentration without Hydrolysis

line hydrolytic products of the three studied drugs with NBD-Cl, show the same characteristic $\lambda_{\max }$ at $460 \mathrm{~nm}$ as shown in Fig. 1. Also from these figures it is clear that, no reaction was observed between the intact drugs and NBD-Cl. So, this method was used for the stability studies of these drugs. Various parameters affecting reaction process were established, the reagent amount required was examined and it was found that $0.6 \mathrm{ml}$ of $0.4 \% \mathrm{w} / \mathrm{v}$ of NBD-Cl reagent was enough to complete the reaction. A greater excess showed no further improvement as shown in Fig. 2.

The $\mathrm{pH}$ dependence of the system was studied in the range of 7.5-10.0 using buffer solutions at different $\mathrm{pH}$. It was found that maximum absorbance was obtained upon using $1 \mathrm{ml}$ of borate buffer $\mathrm{pH} 8$ as shown in Fig. 3 .

Preliminary studies reported that the reaction rate was very slow at room temperature. In this study, the derivatization reaction was performed at different temperatures. The reaction was completed when heating in a boiling water bath for 30 min as shown in Fig. 4.

The absorbance was influenced by the solvent used, the

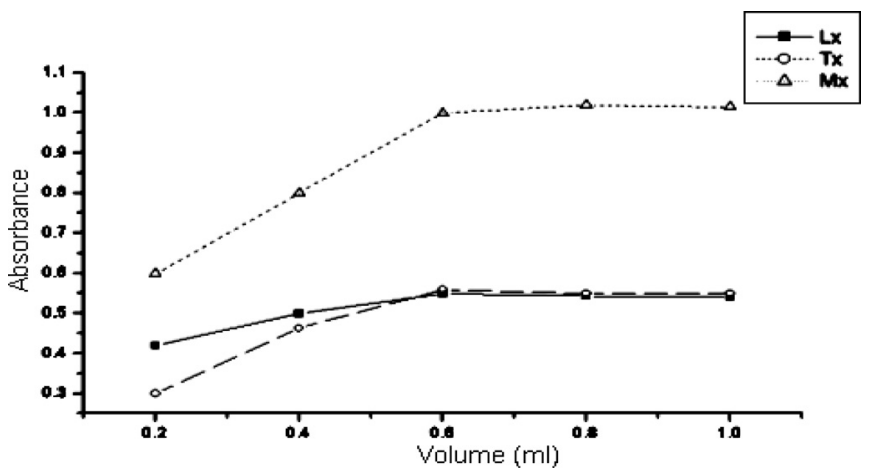

Fig. 2. Effect of NBD-Cl $(0.4 \% \mathrm{w} / \mathrm{v})$ on the Formation of $\mathrm{Lx}, \mathrm{Tx}$ and $\mathrm{Mx}$ Alkaline Degradates Reaction Products $\left(4 \mu \mathrm{g} \mathrm{ml}^{-1}\right)$

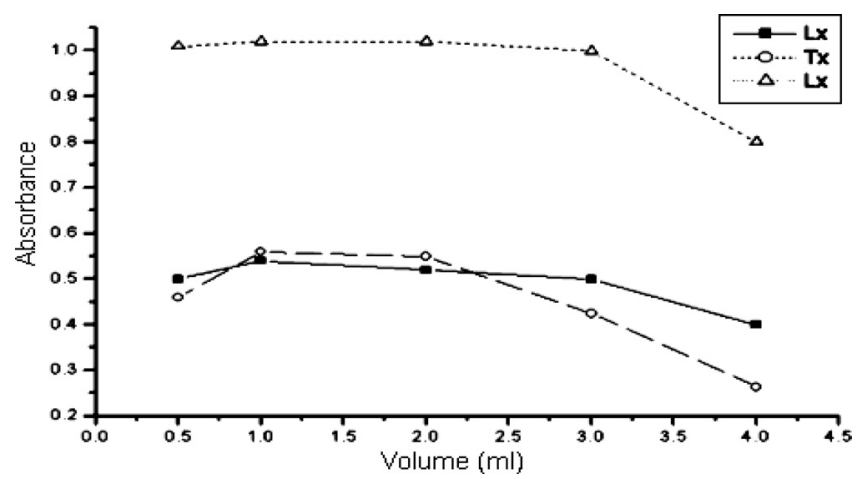

Fig. 3. Effect of Borate Buffer $\mathrm{pH} 8$ on the Formation of Lx, Tx and Mx-Alkaline Degradates Reaction Products $\left(4 \mu \mathrm{g} \mathrm{ml}^{-1}\right)$

derivatives have maximum absorbance in methanol and it was stable in this solvent for at least $48 \mathrm{~h}$ in dark. Under the optimum experimental conditions the calibration curves were plotted representing the relationship between the difference in absorbance at $460 \mathrm{~nm}$ before and after complete alkaline hydrolysis and their corresponding concentrations of pure Lx, Tx and Mx samples.

The concentration range was found to be $1-10 \mu \mathrm{g} \mathrm{ml}^{-1}$ for each of $\mathrm{Lx}$ and Tx, while $0.5-4.0 \mu \mathrm{g} \mathrm{ml}^{-1}$ for Mx.

The suggested method quantitatively determined the studied drugs in their bulk powder with good accuracy and preci- 
sion. The mean percentage recoveries were.

Spectrofluorimetric Method On the same principle a spectrofluorimetric method was developed .The fluorescence spectra of alkaline hydrolytic products with NBD-Cl, show fluorescence intensity at $\lambda_{\mathrm{em}} 535 \mathrm{~nm}$ for the three cited drugs, as shown in Fig. 5. Also, it is clear that no reaction was observed between the intact drugs with NBD-Cl.

After studying of the reaction conditions, it was found that those conditions for spectrophotometric method were optimum for spectrofluorimetric one. The calibration curves

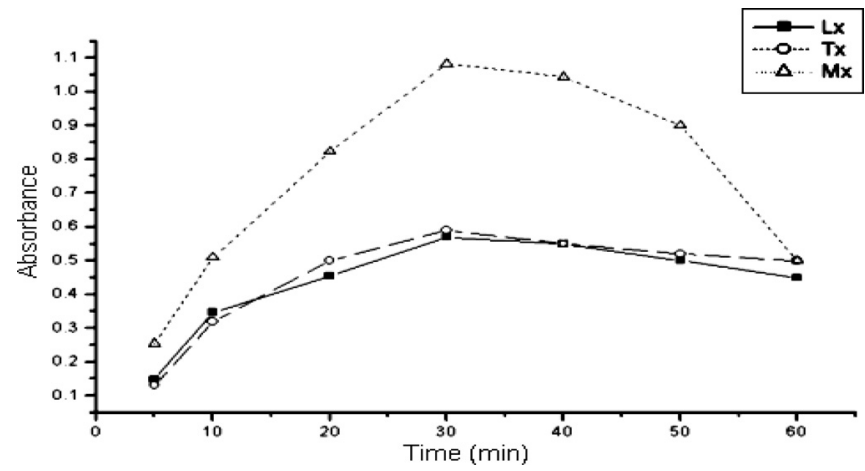

Fig. 4. Effect of Heating Time in Boilling Water Bath on the Formation of Lx, Tx and Mx Alkaline Degradates Reaction Products $\left(4 \mu \mathrm{g} \mathrm{ml}^{-1}\right)$

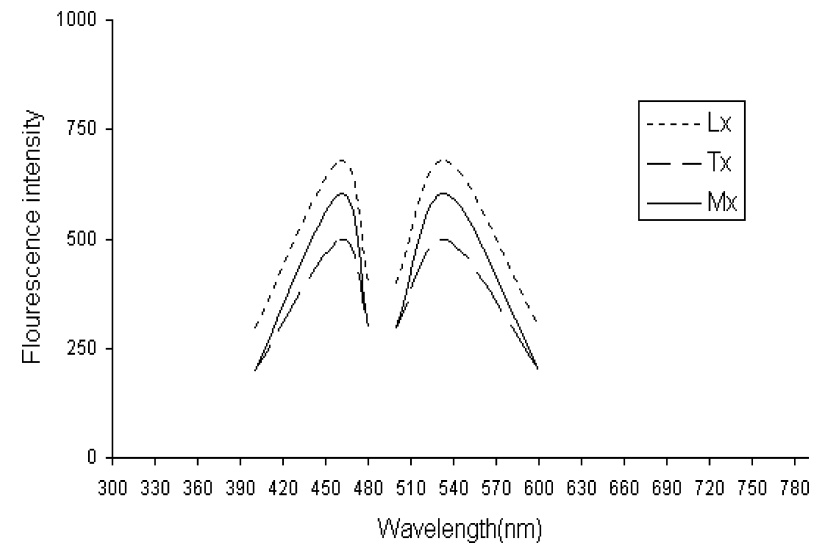

Fig. 5. Excitation and Emission Spectra of $1000 \mathrm{ng} \mathrm{ml}^{-1}$ of Each of Lornoxicam, Lx and Tenoxicam, Tx and $400 \mathrm{ng} \mathrm{ml}^{-1}$ of Meloxicam, MxAlkaline Degradate NBD-Cl Reaction Product $\left(\lambda_{\mathrm{em}} 535 \mathrm{~nm}, \lambda_{\mathrm{ex}} 460 \mathrm{~nm}\right)$ were plotted representing the relationship between the difference in fluorescence intensities at $\lambda_{\text {em }} 535 \mathrm{~nm}$ using $\lambda_{\text {ex }}$ $460 \mathrm{~nm}$ before and after alkaline hydrolysis and their corresponding concentrations of pure Lx, Tx and Mx samples.

The concentration range was found to be (50-1000 $\mathrm{ng} \mathrm{ml}^{-1}$ ) for each of Lx and Tx while (25-400 $\left.\mathrm{ng} \mathrm{ml}^{-1}\right)$ for Mx. The suggested methods were quantitatively determined the three studied drugs in their bulk powder with good accuracy and precision. The mean percentage recoveries were found to be $100.3 \pm 1.1,99.8 \pm 1.1,100.0 \pm 1.0$ for $\mathrm{Lx}$, Tx and $\mathrm{Mx}$ respectively. As for the specificity of the methods Lx, Tx and Mx can be determined in presence of up to $90 \%$ of their alkaline degradates via the proposed methods with good accuracy and precision. The results are shown in Table 1.

The proposed methods were successfully applied for the analysis of the studied drugs in their pharmaceutical dosage forms, Table 2 . The validity was assessed by applying the standard addition technique, the results are shown in Table 3.

Statistical comparison showed that there is no significant difference between the results obtained from the proposed methods and the reported or official methods. The proposed

Table 2. Comparison between the Proposed Methods and the Official or Reported Methods for the Determination of the Studied Drugs in Their Pharmaceutical Dosage Forms

\begin{tabular}{|c|c|c|c|}
\hline Preparations & $\begin{array}{c}\text { Spectro- } \\
\text { photometric } \\
\text { method } \\
\text { Mean recovery }{ }^{a)} \\
\pm \mathrm{RSD}^{2}\end{array}$ & $\begin{array}{c}\text { Spectro- } \\
\text { fluorimetric } \\
\text { method } \\
\text { Mean recovery }{ }^{a)} \\
\pm \mathrm{RSD} \%\end{array}$ & $\begin{array}{c}\text { Official } \\
\text { or reported } \\
\text { method } \\
\text { Mean recovery } \\
\pm \mathrm{RSD} \%\end{array}$ \\
\hline \multicolumn{4}{|l|}{ Lornoxicam } \\
\hline \multicolumn{4}{|l|}{ Xefo tablet } \\
\hline $8 \mathrm{mg} /$ tablet & $99.0 \pm 1.0$ & $99.9 \pm 1.6$ & $100.6 \pm 0.8^{b)}$ \\
\hline $4 \mathrm{mg} /$ tablet & $101.5 \pm 0.8$ & $100.5 \pm 0.8$ & $98.5 \pm 0.9^{b)}$ \\
\hline \multicolumn{4}{|l|}{ Tenoxicam } \\
\hline Epicotil $20 \mathrm{mg}$ tablet & $99.9 \pm 1.7$ & $101.4 \pm 0.8$ & $100.0 \pm 0.8^{c}$ \\
\hline Epicotil $20 \mathrm{mg}$ vial & $101.8 \pm 0.6$ & $98.7 \pm 0.6$ & $97.4 \pm 0.5^{d)}$ \\
\hline \multicolumn{4}{|l|}{ Meloxicam } \\
\hline Anticox II $15 \mathrm{mg}$ tablet & $100.9 \pm 0.9$ & $98.9 \pm 1.5$ & $99.4 \pm 0.7^{e)}$ \\
\hline Anticox II $7.5 \mathrm{mg}$ capsule & e $98.4 \pm 0.9$ & $99.7 \pm 1.7$ & $99.8 \pm 1.2^{e)}$ \\
\hline Anticox II $15 \mathrm{mg}$ ampoule & le $100.8 \pm 1.1$ & $99.6 \pm 1.1$ & $\left.101.1 \pm 0.4^{e}\right)$ \\
\hline
\end{tabular}

a) Average of four different experiments. b) HPLC manufacture procedure supplied by October Pharm. Co., Egypt, by personal communication. c) HPLC method, B.P. 2003. d) Spectrophotometric method, B.P. 2003. e) Spectrophotometric manufacture procedure supplied by Adwia Co., Egypt, by personal communication.

Table 1. Specificity of the Proposed Spectrophotometric and Spectrofluorimetric Methods for the Determination of Lornoxicam, Tenoxicam and Meloxicam in Laboratory Prepared Mixtures with Their Corresponding Alkaline Degradation Products

\begin{tabular}{|c|c|c|c|c|c|c|c|c|}
\hline \multirow{3}{*}{$\begin{array}{c}\text { Degradation } \\
(\%)\end{array}$} & \multicolumn{8}{|c|}{$\%$ Recovery of intact drugs ${ }^{a)}$} \\
\hline & \multicolumn{2}{|c|}{ Lornoxicam } & \multicolumn{3}{|c|}{ Tenoxicam } & \multicolumn{3}{|c|}{ Meloxicam } \\
\hline & $\begin{array}{l}\text { Spectro- } \\
\text { photometric } \\
\text { method }\end{array}$ & $\begin{array}{c}\text { Spectro- } \\
\text { fluorimetric } \\
\text { method }\end{array}$ & $\begin{array}{l}\text { Spectro- } \\
\text { photometric } \\
\text { method }\end{array}$ & $\begin{array}{l}\text { Spectro- } \\
\text { fluorimetric } \\
\text { method }\end{array}$ & $\begin{array}{l}\text { Reported } \\
\text { method }^{b)}\end{array}$ & $\begin{array}{l}\text { Spectro- } \\
\text { photometric } \\
\text { method }\end{array}$ & $\begin{array}{c}\text { Spectro- } \\
\text { fluorimetric } \\
\text { method }\end{array}$ & $\begin{array}{l}\text { Reported } \\
\text { method }^{c)}\end{array}$ \\
\hline 10.0 & 100.5 & 98.8 & 98.5 & 99.7 & 109.8 & 99.8 & 100.5 & 103.5 \\
\hline 20.0 & 98.2 & 100.0 & 101.5 & 100.7 & 115.8 & 100.1 & 101.0 & 105.2 \\
\hline 40.0 & 100.4 & 99.8 & 100.5 & 100.9 & 129.5 & 99.2 & 98.7 & 115.1 \\
\hline 60.0 & 102.0 & 99.6 & 101.1 & 99.5 & 154.2 & 99.2 & 99.3 & 123.0 \\
\hline 80.0 & 98.5 & 100.2 & 100.5 & 98.5 & 178.7 & 100.5 & 98.5 & 130.0 \\
\hline 90.0 & 99.5 & 98.2 & 100.7 & 101.0 & 190.5 & 99.6 & 99.8 & 139.1 \\
\hline Mean \pm RSD (\%) & $99.9 \pm 1.4$ & $99.4 \pm 0.8$ & $100.5 \pm 1.0$ & $100.1 \pm 1.0$ & & $99.7 \pm 0.5$ & $99.6 \pm 1.0$ & \\
\hline
\end{tabular}

a) Average of five different determinations. b) Spectrophotometric method, Florey, K. Analytical Profiles of Drug Substances and Excipients; Academic Press: Inc., 1993, 22, 431-459. c) Spectrophotometry manufacturer procedures upplied by Boehringer Ingelheim, 1993. 
Table 3. Results of Application of Standard Addition Technique, for the Determination of Lornoxicam, Tenoxicam and Meloxicam by the Proposed Methods

\begin{tabular}{|c|c|c|c|c|c|c|}
\hline \multirow{2}{*}{ Preparations } & \multicolumn{3}{|c|}{ Spectrophotometric method } & \multicolumn{3}{|c|}{ Spectrofluorimetric method } \\
\hline & $\begin{array}{l}\text { Amount taken } \\
\left(\mu \mathrm{g} \mathrm{ml}^{-1}\right)\end{array}$ & $\begin{array}{l}\text { Authentic added } \\
\qquad\left(\mu \mathrm{g} \mathrm{ml}^{-1}\right)\end{array}$ & $\begin{array}{c}\text { Found } \\
\text { Recovery }^{a)} \pm \operatorname{RSD}(\%)\end{array}$ & $\begin{array}{l}\text { Amount taken } \\
\left(\mu \mathrm{g} \mathrm{ml}^{-1}\right)\end{array}$ & $\begin{array}{l}\text { Authentic added } \\
\qquad\left(\mu \mathrm{g} \mathrm{ml}^{-1}\right)\end{array}$ & $\begin{array}{c}\text { Found } \\
\text { Recovery }^{a} \pm \text { RSD }(\%)\end{array}$ \\
\hline \multicolumn{7}{|l|}{ Lornoxicam } \\
\hline \multicolumn{7}{|l|}{ Xefo tablet } \\
\hline $8 \mathrm{mg} /$ tablet & 2 & $2-8$ & $99.0 \pm 1.5$ & 0.2 & $0.2-0.8$ & $100.3 \pm 2.0$ \\
\hline $4 \mathrm{mg} /$ tablet & & & $101.3 \pm 0.8$ & & & $100.5 \pm 0.8$ \\
\hline \multicolumn{7}{|l|}{ Tenoxicam } \\
\hline Epicotil $20 \mathrm{mg}$ tablet & 2 & $2-8$ & $101.5 \pm 0.5$ & 0.2 & $0.2-0.8$ & $98.7 \pm 0.6$ \\
\hline Epicotil 20 mg vial & & & $99.7 \pm 0.6$ & & & $101.3 \pm 0.9$ \\
\hline \multicolumn{7}{|l|}{ Meloxicam } \\
\hline Anticox II 15 mg tablet & 1 & $0.5-3$ & $99.6 \pm 1.7$ & 0.1 & $0.05-0.3$ & $99.3 \pm 1.7$ \\
\hline Anticox II $7.5 \mathrm{mg}$ capsule & & & $98.8 \pm 0.7$ & & & $99.7 \pm 0.6$ \\
\hline Anticox II $15 \mathrm{mg}$ ampoule & & & $101.8 \pm 0.3$ & & & $99.5 \pm 0.7$ \\
\hline
\end{tabular}

a) Average of four different experiments.

Table 4. Statistical Comparison between the Results Obtained by the Proposed Methods and the Reported or Official Methods

\begin{tabular}{|c|c|c|c|c|c|c|c|c|c|}
\hline \multirow[b]{2}{*}{ Values } & \multicolumn{3}{|c|}{ Lornoxicam } & \multicolumn{3}{|c|}{ Tenoxicam } & \multicolumn{3}{|c|}{ Meloxicam } \\
\hline & $\begin{array}{l}\text { Spectro- } \\
\text { photometric } \\
\text { method }\end{array}$ & $\begin{array}{l}\text { Spectro- } \\
\text { fluorimetric } \\
\text { method }\end{array}$ & $\begin{array}{l}\text { Reported } \\
\text { method }^{a)}\end{array}$ & $\begin{array}{l}\text { Spectro- } \\
\text { photometric } \\
\text { method }\end{array}$ & $\begin{array}{l}\text { Spectro- } \\
\text { fluorimetric } \\
\text { method }\end{array}$ & $\begin{array}{c}\text { Official } \\
\left.\operatorname{method}^{b}\right)\end{array}$ & $\begin{array}{l}\text { Spectro- } \\
\text { photometric } \\
\text { method }\end{array}$ & $\begin{array}{c}\text { Spectro } \\
\text { fluorimetric } \\
\text { method }\end{array}$ & $\begin{array}{c}\text { Official } \\
\left.\operatorname{method}^{b}\right)\end{array}$ \\
\hline Mean & 99.1 & 100.3 & 100.0 & 99.2 & 99.8 & 99.7 & 99.1 & 100.0 & 99.9 \\
\hline S.D. & 0.8 & 1.0 & 0.7 & 1.0 & 1.1 & 0.9 & 0.8 & 1.0 & 0.8 \\
\hline Variance & 0.6 & 1.0 & 0.5 & 1.0 & 1.2 & 0.8 & 0.6 & 1.0 & 0.6 \\
\hline S.E. & 0.4 & 0.4 & 0.3 & 0.4 & 0.5 & 0.4 & 0.3 & 0.5 & 0.4 \\
\hline$n$ & 5 & 5 & 5 & 5 & 5 & 5 & 5 & 5 & 5 \\
\hline$t(2.306)^{c)}$ & 0.5 & 0.8 & & 0.9 & 0.2 & & 1.6 & 0.1 & \\
\hline$F(6.39)^{c)}$ & 1.2 & 2.0 & & 1.3 & 1.5 & & 1.0 & 1.8 & \\
\hline
\end{tabular}

a) Potentiometry manufacturer procedure supplied by October Pharm. Co. (Egypt), by personal communications. b) Non aqueous titration, the official method B.P. 2003. $c$ ) The values between parenthesis are the theoritical values of $t$ and $F$ at $(p=0.05)$.

Table 5. Results of Assay Validation Obtained by Applying the Proposed Spectrophotometric and Spectrofluorimetric Methods for the Determination of Pure Lornoxicam, Tenoxicam and Meloxicam Samples

\begin{tabular}{|c|c|c|c|c|c|c|}
\hline \multirow[b]{2}{*}{ Parameters } & \multicolumn{2}{|c|}{ Lornoxicam } & \multicolumn{2}{|c|}{ Tenoxicam } & \multicolumn{2}{|c|}{ Meloxicam } \\
\hline & $\begin{array}{l}\text { Spectro- } \\
\text { photometric } \\
\text { method }\end{array}$ & $\begin{array}{l}\text { Spectro- } \\
\text { fluorimetric } \\
\text { method }\end{array}$ & $\begin{array}{l}\text { Spectro- } \\
\text { photometric } \\
\text { method }\end{array}$ & $\begin{array}{l}\text { Spectro- } \\
\text { fluorimetric } \\
\text { method }\end{array}$ & $\begin{array}{l}\text { Spectro- } \\
\text { photometric } \\
\text { method }\end{array}$ & $\begin{array}{l}\text { Spectro- } \\
\text { fluorimetric } \\
\text { method }\end{array}$ \\
\hline Linearity range & $\begin{array}{c}1-10 \\
\left(\mu \mathrm{g} \mathrm{ml}^{-1}\right)\end{array}$ & $\begin{array}{l}5-1000 \\
(\mathrm{ng} / \mathrm{ml})\end{array}$ & $\begin{array}{c}1-10 \\
\left(\mu \mathrm{g} \mathrm{ml}^{-1}\right)\end{array}$ & $\begin{array}{l}50-1000 \\
(\mathrm{ng} / \mathrm{ml})\end{array}$ & $\begin{array}{l}0.5-4.0 \\
\left(\mu \mathrm{g} \mathrm{ml}^{-1}\right)\end{array}$ & $\begin{array}{c}25-400 \\
(\mathrm{ng} / \mathrm{ml})\end{array}$ \\
\hline $\begin{array}{l}\text { Molar absorbitivity } \\
\left(\mathrm{mol}^{-1} \mathrm{~cm}^{-1}\right)\end{array}$ & $4.6 \times 10^{5}$ & & $4.4 \times 10^{5}$ & & $8.9 \times 10^{5}$ & \\
\hline $\begin{array}{l}\text { Accuracy } \\
(\text { mean } \pm \text { RSD\%) }\end{array}$ & $99.1 \pm 0.8$ & $100.3 \pm 1.0$ & $99.2 \pm 1.0$ & $100.8 \pm 1.1$ & $99.1 \pm 0.8$ & $100.0 \pm 1.0$ \\
\hline \multicolumn{7}{|l|}{ Precision } \\
\hline Intraday $^{a)} \mathrm{RSD} \%$ & 0.7 & 1.3 & 0.8 & 1.1 & 1.1 & 1.2 \\
\hline Interday $^{a)} \mathrm{RSD} \%$ & 1.1 & 1.6 & 1.0 & 1.2 & 1.3 & 1.6 \\
\hline $\begin{array}{l}\text { Specificity } \\
(\text { mean土RSD\%) }\end{array}$ & $99.9 \pm 1.4$ & $99.4 \pm 0.8$ & $100.5 \pm 1.0$ & $100.1 \pm 1.0$ & $99.7 \pm 0.5$ & $99.6 \pm 1.0$ \\
\hline \multicolumn{7}{|l|}{ Regression } \\
\hline Slope & 0.1 & 0.5 & 0.1 & 0.4 & 0.3 & 1.0 \\
\hline S.E. of slope & $1.2 \times 10^{-3}$ & $4.4 \times 10^{-3}$ & $6.2 \times 10^{-4}$ & $4.3 \times 10^{-3}$ & $2.0 \times 10^{-3}$ & $7.1 \times 10^{-3}$ \\
\hline Intercept & $6.1 \times 10^{-2}$ & 13.1 & $7.3 \times 10^{-2}$ & 19.9 & $1.3 \times 10^{-2}$ & -5.9 \\
\hline S.E. of intercept & $7.4 \times 10^{-3}$ & 2.4 & $3.8 \times 10^{-3}$ & 2.4 & $5.0 \times 10^{-3}$ & 1.6 \\
\hline Correlation coefficient & 0.9998 & 0.9998 & 0.99995 & 0.9997 & 0.9999 & 0.9999 \\
\hline S.E. of estimation & $9.5 \times 10^{-3}$ & 3.9 & $4.9 \times 10^{-3}$ & 3.8 & $0.6 \times 10^{-3}$ & 2.4 \\
\hline
\end{tabular}

a) $n=9$. 
methods were found to be accurate and precise since the calculated $t$ and $F$ values are less than the tabulated ones as shown in Table 4 . The results of assay validation are represented in Table 5.

\section{Conclusion}

The proposed spectrophotometric and spectrofluorimetric methods provided sensitive, specific, inexpensive and stability indicating analytical procedures for the determination of Lx, Tx and Mx. They can readily be applied for routine quality control testing and drug stability monitoring. Moreover, the spectrofluorimetric method having range sensitive enough for suggesting the ability of application of the method in biological samples, where low concentration level are found.

\section{References}

1) "Merck Index", 13th ed., Merck and Co. Inc., Whitehouse Station, N. J., U.S.A., 2001, p. 1000

2) British Pharmacopoeia, Her, Majestys Stationery Office, London, 2003, p. 1203, 1795, 2661, 2662.

3) Martindale, "The Extra Pharmacopoeia," 33rd ed., The Pharmaceutical Press, London, 2002, p. 50, 51, 87.

4) Gilman A. G., Limbird L. E., Hardman J. G., "The Pharmacological Basis of Therapeutics," 10th ed., Goodman and Gilman's, McGrawHill, New York, U.S.A., 2001, p. 731.

5) Pruss T. P., Stroissnig H., Radhofer-Welte S., Wendtlandt W., Mehdi N., Takacs F., Fellier H., Postgrad. Med. J., 66 (Suppl. 4), S18-S21 (1990).

6) Taha E. A., El-Zanfally E. S., Salama N. N., Sci. Pharm., 71, 303320 (2003).

7) Ghoneim M. M., Beltagi A. M., Radi A., Anal. Sci., 18, 183-186 (2002).

8) Taha E. A., Salama N. N., Abdel Fattah L. S., AOAC Inter., 87, 366$376(2004)$
9) Joseph-Charles J., Bertucat M., J. Liq. Chromatogr. Relat. Technol., 22, 2009-2021 (1999).

10) Radhofer-Welte S., Dittrich P., J. Chromatogr. Biomed. Appl., 707, $151-159$ (1998)

11) El-Ries M. A., Anal. Lett., 31, $793-807$ (1998).

12) AL-Tamrah S. A., Anal. Chim. Acta, 375, 277-283 (1998).

13) Taha E. A., Salama N. N., Abdel Fattah L. S., Spectrosc. Lett., 35, $501-516(2002)$.

14) Barary M. H. Abdel-Hay M. H., Sabry S. M., J. Pharm. Biomed. Anal., 34, 221-226 (2004).

15) Mohamed H. A., Wadood H. M. A., Farghaly O. A., J. Pharm. Biomed. Anal., 28, 819-826 (2002).

16) Atay O., Dincol F., Anal. Lett., 30, 1675-1684 (1997).

17) Atkopar Z., Tuncel M., Anal. Lett., 29, 2383-2397 (1996).

18) Ozaltin N., Anal. Chim. Acta, 406, 183-189 (2000).

19) Khalil S., Borham N., El-Ries M. A., Anal. Chim. Acta, 414, 215219 (2000).

20) Mason J. L., Hobbs G. J., J. Chromatogr. Biomed. Appl., 665, 410415 (1995).

21) Sane R. T., Surve V., Francis M., Indian Drugs, 37, 390-393 (2000).

22) Bebawy L. I., Spectrosc. Lett., 31, 797-820 (1998).

23) Joseph-Charles J., Bertucat M., Anal. Lett., 32, 2051-2059 (1999).

24) Hasan E. M., J. Pharm. Biomed. Anal., 27, 771-777 (2002).

25) Radi A., El-Ries M. A., El-Anwar F., El-Sherif Z., Anal. Lett., 34, 739-748 (2001).

26) Radi A., El-Ries M. A., El-Anwar F., El-Sherif Z., Beltagi A. M., Ghoneim M. M., J. Pharm. Biomed. Anal., 27, 795-801 (2002).

27) Ding L., Chen H., Jiang H., Hou Y. Y., Zhang Z. X., Zhongguo Yiyao Gongye Zazhi, 33, 131-133 (2002).

28) Baeyens W. R. G., Van der Weken G., D'haeninck E., Garcia-Campana A. M., Vankeirsbilck T., Vercauteren A., Deprez P., J. Pharm. Biomed. Anal., 32, 839-846 (2003).

29) Nevin O., Sidika E., Sedef A., J. Pharm. Biomed. Anal., 29, 1-5 (2002).

30) Francois V. H., Aubin H., Anal. Chem., 46, 286-288 (1974).

31) Taha E. A., Anal. Bioanal. Chem., 376, 1131-1136 (2003).

32) El-Emam A. A., Hansen S. H., Moustafa M. A., El-Ashry S. M., ElSherbiny D. T., J. Biomed. Anal., 34, 35-44 (2004). 